\title{
Research on the Popularization of Socialist Core Values Under "Cultivating People Through Culture"*
}

\author{
Rongce Lin \\ College of Tourism \\ Huaqiao University \\ Quanzhou, China
}

\begin{abstract}
Socialist core values and "cultivating people through culture" are dominant and correspondent with each other. Socialist core values are the core content and intensive expression of "cultivating people through culture", which is of great importance to cultivating Socialist Core Values. And they are highly fitted with each other. In the process of popularizing socialist core values, the impact of the West extreme theories, network environment, barriers of feudal superstition, the misleading tendency of the market environment, and other misunderstandings have increased its difficulty. At the same time, the individual differences and the simplified education carriers and methods also affect the effectiveness and progress of the popularization of socialist core values. Therefore, on the basis of paying attention to the differences of individuals, we should actively construct the practice field of "cultivating people through culture", innovate and integrate the approach, and promote the popularization of socialist core values with "cultivating people through culture".
\end{abstract}

Keywords-socialist core values; popularization; cultivating people through culture

\section{INTRODUCTION}

"Core values are the soul of cultural soft power and the focus of its construction. This is the deepest factor that determines the nature and direction of culture..." "Cultivating and promoting socialist core values must be based on the great traditional Chinese culture... Strive to use the cultural wealth created through the Chinese nation to educate people" [1], which shows that the cultivation and practice of socialist core values must be based on the rich cultural implications, and follow the law of cultural development and build an effective mechanism to achieve "cultivating people through culture."

\section{CONNOTATION CHARACTERISTICS OF “CULTIVATING PEOPle THROUGH CULTURE”}

According to the literature, "cultivating people through culture" is agreed through carrying out educational activities to use culture as its content and carrier. On the one hand, it

*Fund Project: Phased Achievements of 2016 Fujian Young and Middle-aged Teacher Education and Research Project (Special Program of Research on Ideological and Political Education in Colleges and Universities) (JZ160344); Phased Achievements of 2017 Fujian Socialist Theory with Chinese Characteristics System Research Center Project (FJ2017ZTB006). emphasizes the need to use the outstanding cultural achievements of Chinese nation to transform people and educate people. On the other hand, it stresses that in the process of education, we should learn from the rich education methods in culture. These two levels interact with each other in an interactive process. In this paper, to grasp the connotation of "cultivating people through culture", we must pay attention to the following aspects:

\section{A. Taking the Quality of Culture as Its Premise}

The quality of culture is an important premise for "cultivating people through culture". It comes from the firm stance of Chinese culture. The inheritance and aesthetics of excellent Chinese culture reflects the conscious and selfconfidence of it, and can help to prevent the spread of various alienation cultures that will influence or dissolve Chinese culture.

\section{B. Taking People as Its Root}

People are the basis of "cultivating people through culture". The interaction between people and culture embodies the dynamic performance of human beings and also reflects the effect that culture has to human beings. This is a two-way construction of the relationship between subject and object. Thus for its combination, educational activities should be carried out from the cultural view point and also people's view point.

\section{Highlighting the Method Will Be the Key}

The process of "humanizing people" is to educate, influence and resolve people in a subtle and intimate way through cultural forms or objects that are well known. The process of "humanizing" includes the method of culture and the way of "cultivating". The method is macroscopic path, and the way is specific operation. [2]

\section{Mechanism Should Bring Field Influence}

In the field of educational activities, culture exists as content, conditions and carriers, and it plays a role in values in a subtle way. What's more, this role is systematic, permeable, and hierarchical. 
III. The InNER RELATIONSHIP BETWEen “CULTIVATING People Through Culture” and Socialist Core Values

\section{A. Leading Relationship: Socialist Core Values Are the Core Content and Intensive Expression of "Cultivating People through Culture"}

The cultural content and form emphasized by "cultivating people through culture" contains various advanced value theories, which carry the spiritual pursuit of the nation and the country. Socialist core values reflect the essential attributes and value orientation of the socialist system [3]. From the perspective of value concept, socialist core values are the essential value connotation of socialist society, the spiritual connotation and value source of various cultural forms and cultural contents, and the core content and intensive expression of "cultivating people through culture".

\section{B. Path Relationship: "Cultivating People Through Culture” Is an Effective Way for Cultivating Socialist Core Values}

General Secretary Xi Jinping pointed out: "Cultivating socialist core value can only be based on the Chinese traditional culture and constantly absorb the spiritual nourishment of the Chinese traditional culture. Only then can we have a profound national foundation, gain widespread recognition from the people, and generate strong cohesiveness and centripetal force.'[3] This indicates that Chinese excellent traditional culture is an important way for cultivating and practicing socialist core values. At the same time, it also emphasizes the need to give full play to the role and function of China's excellent traditional culture, and to absorb all outstanding cultural achievements of mankind with an open mind. It can be seen that "Cultivating people through culture" is an effective path for the cultivation of socialist core values.

\section{Agreement: "Cultivating People through Culture" and Socialist Core Values Are Following the Same Educational Principles}

"Cultivating people through culture" and the cultivation of socialist core values have a high degree of conformity [4]: both are educational activities, reflecting the high degree of consistency of value principle. At the same time, the hierarchical nature of socialist core values determines that "cultivating people through culture" should embody life, and the clarity of its goal also conforms to the purpose of socialist core values.

\section{ANAlysis OF the PREDICAMENT OF SOCIALIST CORE VALUES' POPULARIZATION}

It can be seen from the literature analysis that the popularization of socialist core values covers a wide range of subjects, the value appeals are targeted, and the value content is hierarchical, which is embodied in the consensus of mass values, the improvement of public morality and the shaping of public behavior habits. But there are also difficulties:

\section{A. Difficulty of Popularizing Socialist Core Values Has Increased by Complexity of Multiple and Complex Environments}

1) Impact from Western extreme thinking environment: Under economic globalization, culture is diversified. The extreme erroneous thinking in Western society infiltrates and erode the cultural environment of socialist core values. The wrong trend of thinking has deeply influenced the public's recognition of socialist core values.

2) The negative impact of the network environment: Negative and false information could be spread out by network, which has brought many negative influences, misled and distorted the public's correct understanding of the socialist core values, and weakened the sense of identity.

3) The negative barrier of feudal superstition: Many people regard feudal thinking as their own value pursuit in the absence of scientific discrimination. This not only affects the shaping of their value, but also brings hidden danger to society.

4) Misguidance by market environment's profit-seeking tendency: In the process of market economy development, people have certain deviations from the pursuit of material life and spiritual life. Many people regard the pursuit of material interests as their biggest goal. This tendency of profit-seeking will inevitably lead to distortion of values.

\section{B. The Individual Differences of the Public Influence the \\ Progress of the Popularization of Socialist Core Values}

1) The wideness of the popularization of socialist core values is affected by the degree of public demand: The formation, identification and realization of value goals are all derived from the needs of the subject. Interest is the most direct determinant of the individual's need. The need of the public is directly determined through the benefits brought through socialist core values. However, due to the diversity of individual needs for interests, it is complex to meet people's need.

2) The acceptance of the public influences the depth of the popularization of socialist core values: Acceptance is a kind of psychological identity, focusing on the process from outside to inside. When an individual has a certain need, it will produce an acceptance of something. The popularization of socialist core values depends on the degree of acceptance of the public. This degree of acceptance affects the depth of popularization and is directly influenced by the individual's original thinking and values.

3) Public's practice influences the intensity of the popularization of socialist core values: Only when the socialist core values are truly internalized into the public's beliefs, the public will actually act to practice. To a certain extent, the degree of public demand and acceptance of socialist core values are the premise for the public to practice the core values of socialism, and public's practice directly affects the strength of socialist core values. [5] 
4) The simplification of educational carriers and methods affects the effectiveness of the popularization of socialist core values: The effectiveness of socialist core value depends on the carriers and ways of popularization. The use of rich and effective carriers can promote the popularization of socialist core values better. At present, in the process of promoting the popularization of socialist core values, more publicity and education methods are adopted to inculcate education. Although it has produced certain effects in the implementation process, it inevitably brings certain limitations, mainly reflected in the imbalance between individuals' differences and perfusion education, which is resulted by lacking respect to personal value. Thus we cannot release the differences among individuals and here comes blindly instilling education. In fact, when individuals are satisfied by a certain concept, they are easily conquered to regard it as value orientation. Therefore, we must avoid the simplification of educational carriers and methods, actively expand educational methods, enhance the public's motivation for value pursuit, and enhance the effectiveness of socialist core values.

\section{STRATEGIES FOR OPTIMIZING AND POPULARIZING THE POPULARIZATION OF SOCIALIST CORE VALUES}

\section{A. Actively Constructing the Practice Field of "Cultivating People Through Culture"}

At present, due to the cross-influence of various ideological environments, the masses have shown more individualization and utilitarianism in their thoughts. The mutual stirring of multiple thoughts has increased the difficulty of popularizing socialist core values. Therefore, we must actively construct the practice field of "cultivating people through culture", pay attention to the cultural needs of the masses, influence them from both eye and heart, and enhance the vividness of the socialist core values. As for "cultivating people through culture", people are the object, culture is the carrier, and the purpose of turning people through a certain field of practice can be achieved. The popularization of socialist core values is a kind of education process. This kind of educational activity culture runs through all the time, including the inheritance, acquisition and creation of culture. Bade on the systematic and nonsingularity of cultural action, the consciousness, occasion and environment domain are supposed to be cultivated in the process of constructing practice field, specifically:

1) Cultivate the subjective consciousness domain of the subject: Individual subjective consciousness influences the establishment of subject values. "Cultivating people through culture" is people-oriented and relies on cultural products. People's subjective consciousness is taken as a target, and subjective consciousness can be reflected by cultural products. Therefore, we must first cultivate the subjective consciousness of socialist core values for enhancing subjective recognition. Specifically, it is necessary to establish leaders and demonstrators, give play to their exemplary roles, and fully respect the subjectivity of the public, and cultivate the leaders of "cultivating people through culture".

2) Cultivate the occasion domain of human cultivation: A good educational situation can improve the enthusiasm of the subject and the effectiveness of education. "Cultivating people through culture" emphasizes the influence of culture, and highlights the goal of educational situation in the activities of the people. Therefore, it is necessary to integrate culture and the socialist core values' education situation and cultivate a good socialist core value cultural situation. This kind of cultural situation is inseparable from a variety of cultural and artistic activities. Therefore, we should actively carry out various cultural activities such as art activities, volunteer activities, community activities, etc., and promote the practice of the public.

3) Cultivate the environment domain of cultural products: "Cultivating people through culture" activities are based on culture and cover cultural environment such as material cultural products and spiritual cultural products. This cultural environment represents specific cultural content. Value of "cultivating people through culture" is manifested in the cultural world. Therefore, it is necessary to use cultural products to spread socialist core values, strengthen cultural atmosphere creation, fully respect and understand the individual characteristics of the public, and thus actively create a good self-education atmosphere for educating and guiding people through the cultural environment.

\section{B. Carrying out Education Activities by Paying Attention to Individual's Difference}

"Cultivating people through culture" are guided through the intangible cultural influences on people's subtle influences, while the public's need for value, and their acceptance and practice are different. This difference exists objectively. For promoting the popularization of socialist core values through "cultivating people through culture", it requires to focus on the relationship between culture and human creation. This is also the respect and recognition of the differences between the masses of the public. And we should pay attention to the internal cultivation of the masses, and the development of culture to achieve practice goal of the public.

1) Focus on the internal content of culture and strengthen the internal cultivation of the public: The internal content of culture is the specific cultural concept and value formed through the subject in the process of perceptual recognition of cultural or cultural elements. This endogenous process is a self-introspection process in which individual values are established or revised. The popularization of socialist core values is inseparable from the public's emotional resonance with the core values. As the public's self-recognition continues to strengthen, they will adjust their self-behavior according to social norms and standards, and conduct self-examination. Therefore, it is necessary to strengthen the public's awareness of 
introspection. Realize the internalization of the core values of socialism into their own conscious pursuit of value.

2) Focus on cultural outreach and self-cultivation: When individuals have certain values, their behavior will reflect the norm and correct it automatically. The socialist core values are inseparable from the carrier of life practice. In specific practice, young teachers can better grasp and internalize socialist core values. In cultivating it, they should not only guide them from the ideological perspective, but also strengthen their own social practices, so that young teachers can form a cultural awareness of the socialist core values and transform it into their inner needs.

\section{Innovation and Integration of the "Cultivating People Through Culture" Method}

General Secretary Xi Jinping said, "A value must be integrated into social life, so as to make it really play a role and make people perceive and understand it in practice." [7] From this, we can see that the popularization and promotion of socialist core values requires flexible use of various methods to integrate it into the whole process of public life.

1) Value education method: At present, cultural knowledge education is the most common method to disseminate value through knowledge, and it is also the most traditional method of education through culture. [8] In colleges and universities, classroom value education is the most effective way to carry out value education, so we should give full play to the driving role of the educational atmosphere and strengthen its effect through the teaching activities.

2) Value clarification method: American scholar Laens et al has designed a method of values clarification and appraisal that is applied in classroom teaching, to exert the value education effect of classroom teaching through indirect infiltration and further to help individuals form their values. For this method of value clarification has strong operability, the core values of socialism can be taken as the main line of the method of civic values clarification, to guide the public to integrate and absorb the core values of socialism on the basis of their existing values, and promote the continuous improvement of their ideas.

3) Value attached method: The so-called value attachment method is adopted for the purpose of a certain concept and behavior to enhance or subside, thus give meaning and value to the individual's behavior and activities. Individuals make determination to do it and gain interest through judging the value of behavior and activity. Therefore, through the meaning and value of the behavior behind the activities, individual behaviors can be shaped, so that they can increase their interest in the behavior and enhance the consolidation of behaviors.

4) Value reflection method: Clive Beck, Canada believes that individuals can recall the meaning and value of current life in daily life through reflection, discussion and recognition. With the deepening of understanding, the meaning and value of life will be clearer. [4] This method of value reflection can help individuals to give meaning and value to daily life. Therefore, we should make full use of multicultural knowledge materials to help the public understand the significance of socialist core values to a country, society and individuals and enhance their identity and consciousness.

\section{CONCLUSION}

The core values are the spiritual pillars and souls of the nation, the country, and the individuals. As the important carrier for cultivating and practicing core values, culture is the result of externalization of core values. The socialist core values are the spiritual connotation and value source of various cultural forms and contents, and are the core content and intensive expression of "cultivating people through culture". Study and discussion of it is the use of various cultures conforming to socialism with Chinese characteristics. And the "transformation" through effective paths, is greatly integrated with the purpose of socialist core values. The popularization of socialist core values can help internalize people into their own value pursuits and externalization into behavioral habits of social activities by using simple words and expression. "Cultivating people through culture" actively enhances the public's motivation for value pursuit through intangible culture, which is conducive to enhancing the effectiveness of the popularization of socialist core values.

\section{REFERENCES}

[1] Xi Jinping. Xi Jinping's Discussion on Chinese Traditional Culture Selection of Important Discourses since the 18th National Congress of the Communist Party of China [J] Party Construction. 2014(3): 7-9.

[2] Wang Zhen. On the Implication and Overall Construction of Cultivating People through Culture [J] Research on Ideological Education. 2016(7): 47-51.

[3] Wang Kequn, Shi Shuzhen. Studying General Secretary Xi Jinping's I mportant Exposition on Socialist Core Values [J] Qianjin. 2014(10):23-25.

[4] She Shuanghao. Research on the Methods of Practicing Cultural People and Socialist Core Values [J] Ideological Education Research.2015(12):17-19.

[5] Dou Lichun. The Predicament of the Popularization of Socialist Core Values and Its Response [J]. Journal of Changchun University of Science and Technology (Social Science Edition). 2012 (3): 6-8.

[6] Yu Wende. On the Popularization of Socialist Core Values [J] Scientific Socialism. 2016(8):78-82. 